\title{
PEMODELAN PERTUMBUHAN EKONOMI DI PROVINSI BANTEN MENGGUNAKAN MIXED GEOGRAPHICALLY WEIGHTED REGRESSION
}

Hasbi Yasin, Budi Warsito, Arief Rachman Hakim

Departemen Statistika, Fakultas Sains dan Matematika, Universitas Diponegoro, Indonesia

e-mail: hasbiyasin@live.undip.ac.id

\section{DOI: 10.14710/medstat.11.1.53-64}

\section{Article Info:}

Received: 19 May 2018

Accepted: 8 August 2018

Available Online: 20 August 2018

Keywords:

Banten, Economic growth, MGWR.
Abstract: Economic growth can be measured by amount of Gross Regional Domestic Product (GRDP). Based on official news of statistics BPS, Economic growth in Banten region has increase up to 5.59\%. It supported by several sector, there are agriculture, business, industry and from various fields. Mixed Geographically Weighted Regression (MGWR) methods have been developed based on linear regression by giving spatial effect or location (longitude and latitude), the resulting model from Economic growth in Banten will be local or different based on each location. MGWR mixed method between linear regression and GWR, parameters in linear regression are global and GWR parameters are local. The results more specific because economic growth in Banten region assessed by location.

\section{PENDAHULUAN}

Banten merupakan sebuah provinsi yang terhitung baru, karena mulai menjadi provinsi yang berdiri dari tahun 2000 yang sebelumnya menjadi bagian dari Provinsi Jawa Barat. Bila mengacu rata-rata pertumbuhan ekonomi nasional sebesar 5,19\%, pertumbuhan ekonomi di Banten cukup tinggi yaitu sebesar 5,95 \%. Bila melihat pada empat triwulan terakhir terjadi peningkatan, mulai dari 5,52\% pada triwulan kedua tahun 2017, 5,62\% pada triwulan ketiga tahun 2017, 5,75\% pada triwulan keempat tahun 2017, dan mencapai 5,95\% pada triwulan pertama tahun 2018 (BPS, 2018).

Hal ini turut didukung dari beberapa sektor lapangan usaha dan jumlah dari komoditi ekspor yang turut mengalami kenaikan. Belum banyak penelitian yang mengkaji pertumbuhan ekonomi di Banten, apabila pemodelan pertumbuhan ekonomi dilakukan dengan menggunakan metode regresi linier, model yang dihasilkan tidak akan cukup bisa menggambarkan keadaan per wilayah di Banten. Hal ini disebabkan parameter-parameter pada model regresi linier berlaku secara global atau keseluruhan, sehingga tidak akan ada perbedaan model antar wilayahnya. Padahal apabila dikaji lebih dalam dari faktor lokasi, beberapa Kabupaten/Kota di Banten memiliki karakteristik yang berbeda-beda. Pemodelan dengan menggunakan Mixed Geographically Weighted Reggression (MGWR) akan menghasilkan model yang berbeda-beda antara setiap lokasi pengamatan, tentu saja dengan faktor-faktor yang berbeda-beda pula (Fotheringham et al., 2002). Model MGWR telah 
terbukti merupakan model yang handal dalam mengatasi adanya efek campuran dalam model regresi linier, seperti penelitian tentang pemodelan Indeks Standar Pencemaran Udara (Ispriyanti et al., 2017) dan penelitian tentang pemetaan konsentrasi kandungan $\mathrm{SO}_{2}$ (Winarso dan Yasin, 2016). Berdasarkan penelitian tersebut disimpulkan bahwa model spasial GWR dapat meningkatkan nilai akurasi model (Koefisien Determinasi) secara signifikan.

Metode MGWR adalah gabungan dari metode regresi linier dengan metode Geographically Weighted Reggression (GWR), dimana model yang akan dihasilkan dari regresi linier akan bersifat global (menyeluruh) dan GWR akan menghasilkan model yang bersifat lokal (spesifik untuk setiap lokasi) (Yasin et al., 2017). Maka dari itu model yang akan dihasilkan adalah model campuran lokal dan global, dimana dalam model GWR tidak mencantumkan parameter yang berpengaruh secara global padahal hal tersebut juga turut mempengaruhi variabel respon. Oleh karena itu, metode MGWR akan diaplikasikan dalam pemodelan pertumbuhan ekonomi di provinsi Banten untuk mengetahui faktor-faktor yang berpengaruh terhadap pertumbuhan ekonomi di Banten serta untuk mengetahui faktorfaktor apa saja yang bersifat lokal maupun global.

\section{TINJAUANPUSTAKA}

\subsection{Regresi Linier}

Analisis regresi merupakan sebuah metode statistika yang digunakan untuk memodelkan hubungan antara variabel respon (Y) dengan variabel prediktor (X) (Draper dan Smith, 1992). Proses analisis regresi linier mengharuskan beberapa asumsi klasik yaitu normalitas, nonmultikolinearitas, homoskesdatisitas, non autokorelasi. Parameter yang dihasilkan pada model regresi linier akan bersifat keseluruhan/umum untuk semua lokasi (global). Model regresi dengan $n$ lokasi dan $p$ variabel prediktor dapat dituliskan sebagai berikut:

$$
y_{i}=\beta_{0}+\sum_{k=1}^{p} \beta_{k} x_{i k}+\varepsilon_{i}, i=1,2, \ldots, n \text { dan } k=1,2, \ldots, p
$$

Apabila Persamaan (1) ditulis dalam bentuk matriks menjadi:

$$
\mathbf{y}=\mathbf{X} \boldsymbol{\beta}+\boldsymbol{\varepsilon}
$$

Estimasi parameter untuk model regresi linier didapat dengan menggunakan metode Ordinary Least Square (OLS) kemudian di tuliskan dalam bentuk matriks adalah sebagai berikut :

$$
\hat{\boldsymbol{\beta}}=\left(\mathbf{X}^{T} \mathbf{X}\right)^{-1} \mathbf{X}^{T} \mathbf{y}
$$

\subsection{Model Geographically Weighted Regression (GWR)}

GWR merupakan pengembangan dari model regresi linier dimana setiap parameter dihitung berdasarkan setiap lokasi pengamatan sehingga parameter yang didapatkan akan berbeda-beda atau bersifat lokal (Fotheringham, et al., 2002). Model GWR seperti halnya model regresi linier sederhana namun ada penambahan unsur lokasi, yaitu koordinat geografis $\left(u_{i}, v_{i}\right)$ seperti yang dituliskan oleh persamaan berikut: 


$$
y_{i}=\beta_{0}\left(u_{i}, v_{i}\right)+\sum_{k=1}^{p} \beta_{k}\left(u_{i}, v_{i}\right) x_{i k}+\varepsilon_{i}, i=1,2, \ldots, n \operatorname{dan} k=1,2, \ldots, p
$$

Secara matriks dapat ditulis sebagai berikut:

$$
\mathbf{y}=\mathbf{X} \boldsymbol{\beta}\left(u_{i}, v_{i}\right)+\boldsymbol{\varepsilon}, \quad i=1,2, \ldots, n
$$

Persamaan 4 kemudian diestimasi menggunakan teknik estimasi yang hampir sama dengan regresi linier namun menggunakan bobot lokasi, metode estimasi tersebut adalah Weighted Least Square (WLS). Sehingga didapatkan penaksir parameter model GWR (Purhadi dan Yasin, 2012) sebagai berikut:

$$
\hat{\boldsymbol{\beta}}\left(u_{i}, v_{i}\right)=\left(\mathbf{X}^{T} \mathbf{W}\left(u_{i}, v_{i}\right) \mathbf{X}\right)^{-1} \mathbf{X}^{T} \mathbf{W}\left(u_{i}, v_{i}\right) \mathbf{Y} \text {, untuk } i=1,2, \ldots, n
$$

dengan $\mathbf{W}\left(u_{i}, v_{i}\right)=\operatorname{diag}\left[W_{1}\left(u_{i}, v_{i}\right), \ldots, W_{n}\left(u_{i}, v_{i}\right)\right]$ merupakan matriks fungsi pembobot. Pembobotan pada model GWR ini sendiri dapat dilakukan dengan menggunakan beberapa fungsi kernel jarak yaitu fungsi Gaussian, Exponential, Bisquare, Tricube (Lesage, 2001). Pembobot yang digunakan dalam penelitian ini fungsi kernel jarak Gaussian (Gaussian Distance Kernel Function), dengan fungsi pembobot dapat ditulis sebagai berikut:

$$
w_{j}\left(u_{i}, v_{i}\right)=\phi\left(d_{i j} / \sigma h\right)
$$

Dengan $\phi$ adalah densitas normal standar dan $\sigma$ menunjukkan simpangan baku dari vektor jarak $d_{i j}$ (jarak Euclid) serta $h$ adalah parameter non negatif yang diketahui dan biasanya disebut parameter penghalus (bandwidth) (Lesage 2001). Untuk mengidentifikasi faktor faktor-faktor yang berpengaruh secara lokal dapat menggunakan pendekatan uji $\mathrm{F}$ yang telah dipublikasikan oleh Mei, et al. (2006).

\subsection{Model Mixed Geographically Weighted Regression (MGWR)}

Berbeda dengan model GWR yang tidak mengakomodasi parameter yang bersifat global, maka dalam model MGWR akan terdapat parameter yang bersifat lokal dan ada parameter yang bersifat global. Pada model MGWR beberapa koefisien pada model GWR diasumsikan sama untuk seluruh lokasi pengamatan sedangkan yang lain bervariasi sesuai lokasi pengamatan data (Fotheringham, et al., 2002). Model MGWR dengan sebanyak $q$ variabel prediktor bersifat lokal dapat dituliskan sebagai berikut:

$$
y_{i}=\beta_{0}\left(u_{i}, v_{i}\right)+\sum_{k=1}^{q} \beta_{k}\left(u_{i}, v_{i}\right) x_{i k}+\sum_{k=q+1}^{p} \beta_{k} x_{i k}+\varepsilon_{i}, i=1,2, \ldots, n
$$

Kemudian Persamaan 6 dapat ditulis dalam bentuk matriks

$$
\mathbf{y}=\mathbf{X}_{l} \boldsymbol{\beta}_{l}\left(u_{i}, v_{i}\right)+\mathbf{X}_{g} \boldsymbol{\beta}_{g}+\boldsymbol{\varepsilon}
$$

dengan

$$
\mathbf{X}_{l}=\left(\begin{array}{cccc}
1 & x_{11} & \cdots & x_{1 q} \\
1 & x_{21} & \cdots & x_{2 q} \\
\vdots & \vdots & \ddots & \vdots \\
1 & x_{n 1} & \cdots & x_{n q}
\end{array}\right), \mathbf{X}_{g}=\left(\begin{array}{cccc}
x_{1,(q+1)} & x_{1,(q+2)} & \cdots & x_{1 p} \\
x_{2,(q+1)} & x_{2,(q+2)} & \cdots & x_{2 p} \\
\vdots & \vdots & \ddots & \vdots \\
x_{n,(q+1)} & x_{n,(q+2)} & \cdots & x_{n p}
\end{array}\right),
$$




$$
\boldsymbol{\beta}_{l}\left(u_{i}, v_{i}\right)=\left(\begin{array}{c}
\beta_{0}\left(u_{i}, v_{i}\right) \\
\beta_{1}\left(u_{i}, v_{i}\right) \\
\vdots \\
\beta_{q}\left(u_{i}, v_{i}\right)
\end{array}\right), \text { dan } \boldsymbol{\beta}_{g}=\left(\begin{array}{c}
\beta_{q+1} \\
\beta_{q+2} \\
\vdots \\
\beta_{p}
\end{array}\right)
$$

Estimasi parameter untuk model MGWR menggunakan teknik yang sama dengan GWR yaitu dengan menggunakan Weighted Least Square (WLS). Estimasi parameter lokal maupun global model MGWR sebagai berikut (Yasin, et al., 2017):

$$
\begin{gathered}
\hat{\boldsymbol{\beta}}_{g}=\left[\mathbf{X}_{g}^{T}\left(\mathbf{I}-\mathbf{S}_{l}\right)^{T}\left(\mathbf{I}-\mathbf{S}_{l}\right) \mathbf{X}_{g}\right]^{-1} X_{g}^{T}\left(\mathbf{I}-\mathbf{S}_{l}\right)^{T}\left(\mathbf{I}-\mathbf{S}_{l}\right) \mathbf{y} \\
\hat{\boldsymbol{\beta}}_{l}\left(u_{i}, v_{i}\right)=\left[\mathbf{X}_{l}^{T} \mathbf{W}\left(u_{i}, v_{i}\right) \mathbf{X}_{l}\right]^{-1} \mathbf{X}_{l}^{T} \mathbf{W}\left(u_{i}, v_{i}\right)\left(\mathbf{y}-\mathbf{X}_{g} \hat{\boldsymbol{\beta}}_{g}\right)
\end{gathered}
$$

dengan

$$
\begin{aligned}
\mathbf{S}_{l} & =\left(\begin{array}{c}
\mathbf{x}_{l 1}^{T}\left[\mathbf{X}_{l}^{T} \mathbf{W}\left(u_{i}, v_{i}\right) \mathbf{X}_{l}\right]^{-1} \mathbf{X}_{l}^{T} \mathbf{W}\left(u_{i}, v_{i}\right) \\
\mathbf{x}_{l 2}^{T}\left[\mathbf{X}_{l}^{T} \mathbf{W}\left(u_{i}, v_{i}\right) \mathbf{X}_{l}\right]^{-1} \mathbf{X}_{l}^{T} \mathbf{W}\left(u_{i}, v_{i}\right) \\
\vdots \\
\mathbf{x}_{\ln }^{T}\left[\mathbf{X}_{l}^{T} \mathbf{W}\left(u_{i}, v_{i}\right) \mathbf{X}_{l}\right]^{-1} \mathbf{X}_{l}^{T} \mathbf{W}\left(u_{i}, v_{i}\right)
\end{array}\right) \\
\mathbf{S}_{g} & =\mathbf{X}_{g}\left[\mathbf{X}_{g}^{T} \mathbf{X}_{g}\right]^{-1} \mathbf{X}_{g}^{T} \\
\mathbf{x}_{l i}^{T} & =\left(1, x_{i 1}, x_{i 2}, \cdots, x_{i q}\right)
\end{aligned}
$$

$\hat{\boldsymbol{\beta}}_{g}$ merupakan parameter yang bersifat global, $\hat{\boldsymbol{\beta}}_{l}\left(u_{i}, v_{i}\right)$ merupakan parameter berlaku secara lokal. Pengujian kesesuaian model MGWR dilakukan dengan membandingkan model MGWR dengan model regresi global, lalu setelah dilakukan uji kesesuaian model dilakukan uji serentak yang pertama untuk parameter variabel prediktor global, dan yang kedua untuk parameter variabel prediktor lokal. Selanjutnya dilakukan uji parsial dengan tujuan untuk mengetahui variabel global dan lokal yang berpengaruh signifikan terhadap respon pada model MGWR, hal ini mengacu pada penelitian sebelumnya yang dilakukan oleh Purhadi dan Yasin (2012) dan Hakim, et al. (2014).

\subsection{Pemilihan Model Terbaik}

Ada beberapa metode yang digunakan untuk memilih model terbaik, diantaranya adalah Akaike Information Criterion (AIC) dan $\mathrm{R}^{2}$, yang didefinisikan sebagai berikut:

$$
A I C_{c}=2 n \ln (\hat{\sigma})+n \ln (2 \pi)+n\left\{\frac{n+\operatorname{tr}(\mathbf{S})}{n-2-\operatorname{tr}(\mathbf{S})}\right\}
$$

dengan :

$$
\begin{aligned}
& \hat{\sigma} \text { : Nilai estimator standar deviasi dari error hasil estimasi maksimum } \\
& \text { likelihood, yaitu } \hat{\sigma}^{2}=\frac{S S E}{n} \\
& \mathbf{S}: \text { Matriks proyeksi dimana } \hat{\mathbf{y}}=\mathbf{S y}
\end{aligned}
$$


Menurut Gujarati (1999), nilai koefisien determinasi $\mathrm{R}^{2}$ menunjukkan proporsi atau persentase variasi total dalam variabel respon $(\mathrm{Y})$ yang dijelaskan oleh variabel prediktor $(\mathrm{X})$. Gagasan $\mathrm{R}^{2}$ ini digunakan untuk model regresi yang berisi lebih dari dua variabel. Pemilihan model terbaik dilakukan dengan menentukan model dengan nilai AIC terkecil dan $\mathrm{R}^{2}$ terbesar (Fotheringham, et al., 2002).

\subsection{Teori Pertumbuhan Ekonomi}

Tingkat pertumbuhann ekonomi merupakan gambaran mengenai kenaikan riil dari produksi barang dan jasa yang dihasilkan oleh suatu negara pada periode tertentu. Pembangunan ekonomi adalah pertumbuhan ekonomi ditambah dengan perubahan. Terdapat beberapa macam alat yang dapat digunakan untuk mengukur pertumbuhan ekonomi yaitu Produk Domestik Bruto (PDB) atau Produk Domestik Regional Bruto (PDRB) maupun PDB Per Kapita (PDRB Per Kapita) (Prabowo, et al., 2015). Ada beberapa faktor yang di anggap mempengaruhi pertumbuhan ekonomi yaitu:1. Sumber Daya Alam; 2. Human Capital; 3. Modal; 4. Sektor Wirausaha; 5. Angkatan Kerja; dan 6. Kemajuan Teknologi (Irwan, et al., 2002).

\section{METODE PENELITIAN}

\subsection{Variabel Penelitian}

Pada penelitian ini menggunakan data yang diperoleh dari BPS Banten pada tahun 2013-2016.Data tersebut berupa data PDRB provinsi Banten pertahun meliputi semua kabupaten dan kota selama 4 tahun terakhir, yang kemudian digunakan sebagai variabel respon (Y). Data tersebut terdapat pada publikasi Banten Dalam Angka dan Berita Resmi Statistika.

Pada dasarnya pertumbuhan ekonomi dipengaruhi 6 faktor utama yaitu Sumber Daya Alam, Human Capital, Modal, Sektor Wirausaha, Angkatan Kerja, dan Kemajuan Teknologi. Adapun pemilihan variabel prediktor (X) pada penelitian ini, merupakan repesentasi dari 6 faktor utama tersebut. Faktor sumber daya alam direpresentasikan oleh hasil/produktivitas padi dan jagung, faktor modal direpesentasikan oleh variabel modal yang diperoleh baik dari Pemda maupun modal asing dan realisasi penerimaan Pajak Bumi Bangunan, faktor human capital direpesentasikan oleh angka kepandaian membaca serta menulis, Upah Minimum Regional dan rata-rata lama sekolah. Faktor wirausaha direpresentasikan oleh jumlah perusahaan atau industri. Untuk faktor angkatan kerja dan kemajuan teknologi tidak didapatkan data yang sesuai dan lengkap yang mengcover seluruh Kabupaten dan Kota yang ada di Provinsi Banten empat tahun terakhir. Maka dari itu yang digunakan dalam penelitian ini adalah empat faktor utama yaitu sumber daya alam, modal, human capital dan wirausaha. Sehingga variabel yang digunakan dalam penelitian ini adalah:Modal Bersumber Pemda $\left(\mathrm{X}_{1}\right)$, Total industri besar dan sedang $\left(\mathrm{X}_{2}\right)$, Produktivitas Padi $\left(\mathrm{X}_{3}\right)$, Produktivitas Jagung $\left(\mathrm{X}_{4}\right)$, Realisasi PBB $\left(\mathrm{X}_{5}\right)$, Angka kepandaian membaca dan menulis $\left(\mathrm{X}_{6}\right)$, Upah Minimum Regional $\left(\mathrm{X}_{7}\right)$, Rata-rata lama sekolah $\left(\mathrm{X}_{8}\right)$ dan Modal bersumber dari investasi asing ( $\mathrm{X}_{9}$ ) (Prabowo, et al., 2015).

\subsection{Tahapan Analisis Data}

Penelitian ini dilakukan dengan tahapan sebagai berikut:

1. Membuat pemodelan regresi linier (global) beserta analisisnya

2. Membuat pemodelan GWR beserta analisisnya 
3. Membuat pemodelan MGWR beserta analisisnya

4. Membandingkan ketiga model untuk memperoleh model terbaik.

\section{HASIL DAN PEMBAHASAN}

Berikut pemetaan pertumbuhan ekonomi di Banten berdasarkan kabupaten dan kota pada tahun 2015 dan 2016.

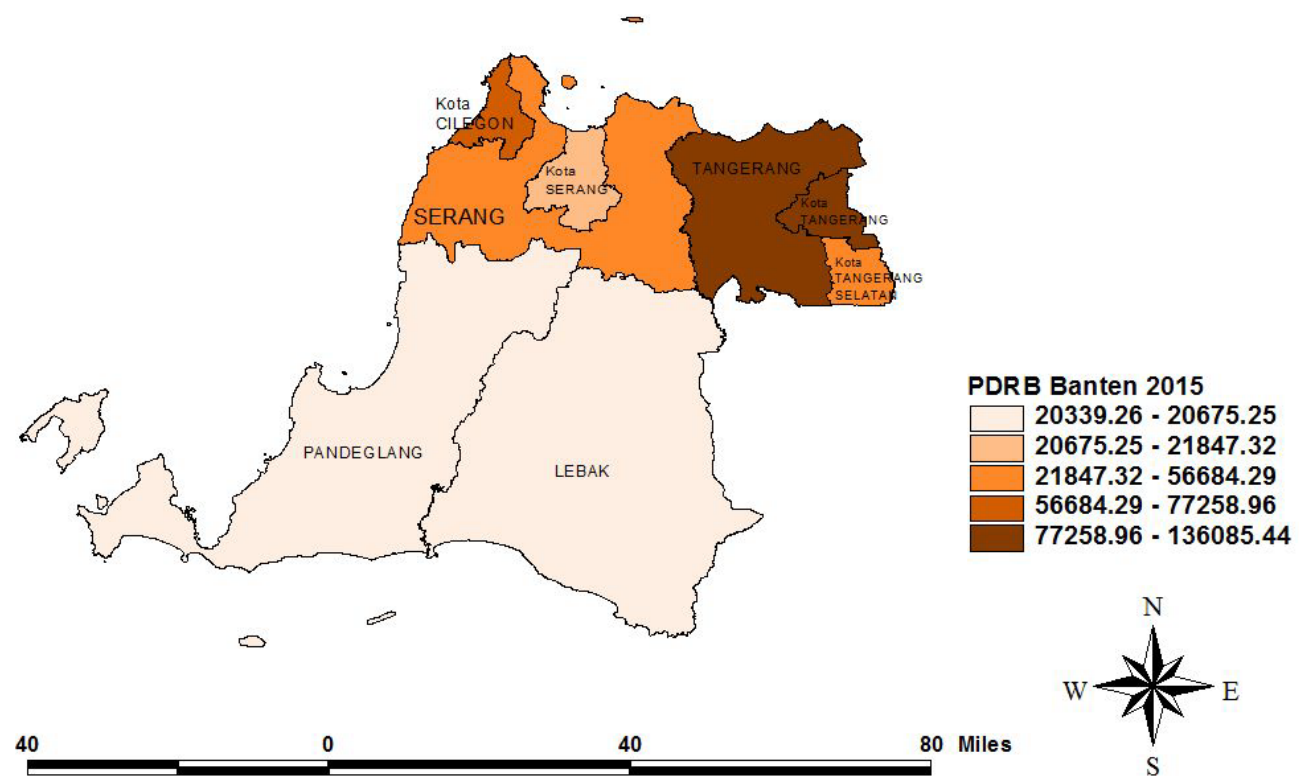

Gambar 1 Pemetaan Pertumbuhan Ekonomi Banten 2015

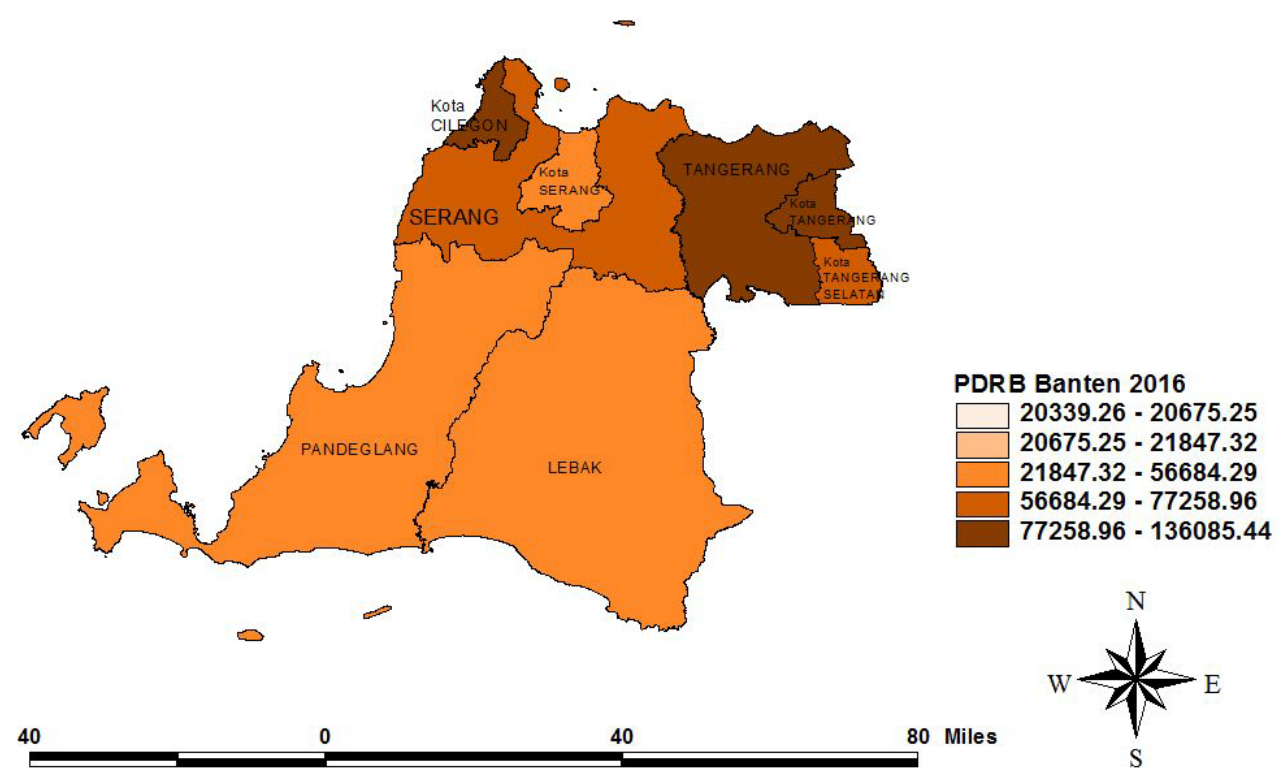

Gambar 2 Pemetaan Pertumbuhan Ekonomi Banten 2016

Apabila mengacu pada data pertumbuhan ekonomi di Banten 2015 sampai 2016 dapat dikatakan bahwa pertumbuhan ekonomi didominasi beberapa daerah yaitu Kabupaten Tangerang dan Kota Tangerang, untuk Kabupaten Lebak dan Pandeglang 
merupakan daerah dengan pertumbuhan ekonomi terendah di Provinsi Banten. Hal ini didukung faktor geografis daerah tersebut, pada Kabupaten Lebak dan Pandeglang masih jarang terdapat sektor-sektor industri dengan skala besar dan menengah, daerah tersebut sebagian besar secara geografis masih kawasan pedesaan dan hutan, dengan komoditas utama dari sektor pertanian dan hasil alam lainnya.

Lain halnya di Kabupaten Tangerang dan Kota Tangerang terdapat banyak perusahaan industri baik dari skala sedang hingga besar, tentunya hal ini turut mempengaruhi pola perekonomian penduduk di daerah tersebut. Komoditas utama di daerah ini tentu saja barang-barang hasil produksi dari perusahaan-perusahaan industri, baik berupa tekstil, makanan, minuman maupun obat-obatan dengan skala pemakaian dalam negeri maupun skala ekspor. Bila melihat pada Gambar 1 dan 2, Kota Cilegon termasuk dalam kota dengan petumbuhan ekonomi yang cukup tinggi diatas Kota Serang dan dibawah Kota Tangerang. Secara geografis Kota Cilegon berbatasan langsung dengan Kota Serang, serta terdapat beberapa perusahaan serta industri dengan skala besar lebih banyak bila dibandingkan dengan Kota Serang ditambah lagi Kota Cilegon merupakan jalur penyebrangan selat sunda yang menghubungkan antara pulau Jawa dan Sumatera.

\subsection{Aplikasi Model Regresi Linier}

Hasil yang diperoleh dengan menggunakan metode regresi linier antara variabel respon (Y) dan prediktor (X), setelah semua asumsi klasik terpenuhi didapatkan bahwa secara simultan dengan mengunakan taraf signifikansi $\alpha$ sebesar 5\% model signifikan yang artinya secara keseluruhan model tersebut dapat digunakan. Setelah itu dilakukan pengujian parsial sehingga didapatkan hasil bahwa hanya ada 3 variabel yang berpengaruh signifikan terhadap pertumbuhan ekonomi yaitu variabel banyaknya perusahaan atau industri $\left(\mathrm{X}_{2}\right)$, kepandaian membaca dan menulis masyarakat banten $\left(\mathrm{X}_{6}\right)$, lalu rata-rata lama sekolah $\left(\mathrm{X}_{8}\right)$. Sehingga modelnya dapat dituliskan sebagai berikut:

$$
\hat{Y}=0,8005 X_{2}+0,22258 X_{6}+0,2958 X_{8}
$$

Dengan koefisien determinasi sebesar $87,6 \%$ yang artinya variabel prediktor berpengaruh terhadap variabel respon sebesar $87,6 \%$ sedangkan sisanya sebesar $12,4 \%$ dipengaruhi oleh faktor lain di luar model.

\subsection{Aplikasi Model Geographically Weighted Reggression (GWR)}

Langkah pertama dalam proses GWR yaitu melakukan pengujian hipotesis apakah terdapat perbedaan antara model GWR yang dihasilkan dengan regresi global. Uji hipotesis yang digunakan adalah sebagai berikut:

$$
\begin{aligned}
H_{0}: & \beta_{k}\left(u_{i}, v_{i}\right)=\beta_{k} \text { Untuk setiap } k=1,2, \ldots, 9 \text { dan } i=1,2, \ldots, 8 \\
& \text { (tidakterdapat perbedaan yang signifikan antara model regresi dengan } \\
& \text { GWR) } \\
H_{1}: & \text { Minimal ada satu } \beta_{k}\left(u_{i}, v_{i}\right) \neq \beta_{k} \text { Untuk setiap } k=1,2, \ldots, 9 \text { dan } i=1,2, \ldots 8 \\
& \text { (terdapat perbedaan yang signifikan antara model regresi dan GWR). }
\end{aligned}
$$

Berdasarkan hasil pada Tabel 1 yang diperoleh dari model GWR diperoleh nilai statistik F sebesar 2,2516 (sig. =0,0578), apabila menggunakan taraf signifikansi $\alpha$ 
sebesar 5\% maka model GWR secara simultan atau bersama disimpulkan dengan menambahkan faktor lokasi model yang didapatkan tidak berbeda dengan regresi linier. Namun apabila digunakan taraf signifikansi $\alpha$ sebesar $10 \%$ dengan $p$-value sebesar $0,0578(<0.10)$ dapat disimpulkan bahwa model GWR berbeda signifikan dengan model regresi global.

Selanjutnya dilakukan uji pengaruh lokasi secara parsial dengan hasil diberikan pada Tabel 1.

Tabel 1 Uji kesesuaian model dan pengaruh lokasi secara parsial model GWR

\begin{tabular}{lrrrrr}
\hline \multicolumn{7}{c}{ Output uji kesesuaian model GWR } \\
\hline Sumber keragaman & SS & df & MS & F & P-value \\
\hline Improvement & 1,4128 & 7,1458 & 0,1977 & 2,2516 & 0,0578 \\
GWR & 1,3043 & 14,8542 & 0,0878 & & \\
Regresi & 2,7170 & 22,0000 & & & \\
\hline \multicolumn{7}{c}{ Uji pengaruh lokasi secara } & & & \\
\hline Variabel (X) & F3 Stat & P Value & $\alpha=5 \%$ & $\alpha=10 \%$ \\
\hline 1 & 76,517 & 0,0068 & Signifikan & Signifikan \\
2 & 43,824 & 0,0297 & Signifikan & Signifikan \\
3 & 10,079 & 0,3926 & Tidak Signifikan & Tidak Signifikan \\
4 & 15,367 & 0,2416 & Tidak Signifikan & Tidak Signifikan \\
5 & 29,292 & 0,0784 & Tidak Signifikan & Signifikan \\
6 & 11,942 & 0,3269 & Tidak Signifikan & Tidak Signifikan \\
7 & 12,605 & 0,3041 & Tidak Signifikan & Tidak Signifikan \\
8 & 23,266 & 0,1242 & Tidak Signifikan & Tidak Signifikan \\
9 & 0,4662 & 0,5784 & Tidak Signifikan & Tidak Signifikan \\
\hline
\end{tabular}

Pada Tabel 1 dengan menggunakan tingkat signifikansi sebesar $\alpha$ maka bila $P$ value $<\alpha$ artinya dapat dikatakan bahwa untuk variabel prediktor $\left(X_{k}\right)$ ada perbedaan antara satu lokasi dengan lokasi lainnya. Langkah selanjutnya adalah pengujian signifikansi parameter model. Pengujian ini dilakukan untuk mengetahui parameter mana saja yang signifikan mempengaruhi variabel responnya. Pada proses estimasi parameter terdapat empat jenis tipe pembobotan yaitu Gaussian, Exponential, Bisquare, Tricube. Tidak ada keharusan dalam memilih jenis pembobot, dalam penelitian ini parameter GWR yang dihasilkan menggunakan pembobot Gaussian. Dalam prosedur pembobotan sendiri menggunakan bandwith yang optimum, metode Cross Validation (CV) digunakan untuk memilih bandwith yang optimum, dengan ketentuan bandwith optimum tercapai dengan meminimumkan CV. Tabel 2 menunjukkan hasil estimasi parameter model GWR dan pengujiannya.

Tabel 2 Estimasi Parameter Model GWR dengan Pembobot Gaussian

\begin{tabular}{lccccccc}
\hline Kabupaten/Kota & $\begin{array}{c}\text { Beta } \\
\text { konstan }\end{array}$ & $\begin{array}{c}\text { Beta } \\
\left(\mathbf{X}_{\mathbf{1}}\right)\end{array}$ & $\begin{array}{c}\text { Beta } \\
\left(\mathbf{X}_{\mathbf{2}}\right)\end{array}$ & $\begin{array}{c}\text { Beta } \\
\left(\mathbf{X}_{5}\right)\end{array}$ & $\begin{array}{c}\mathbf{P}_{\mathbf{2}} \text { value } \\
\left(\mathbf{X}_{\mathbf{1}}\right)\end{array}$ & $\begin{array}{c}\text { P_value } \\
\left(\mathbf{X}_{\mathbf{2}}\right)\end{array}$ & $\begin{array}{c}\text { P_value } \\
\left(\mathbf{X}_{\mathbf{5}}\right)\end{array}$ \\
\hline Pandeglang & $-0,059$ & 0,205 & 0,564 & 0,104 & 0,021 & 0,000 & 0,372 \\
Lebak & $-0,089$ & $-0,007$ & 0,697 & 0,105 & 0,469 & 0,000 & 0,114 \\
\hline
\end{tabular}




\begin{tabular}{lrrrrrrr}
\hline Tangerang & $-0,096$ & $-0,106$ & 0,914 & 0,283 & 0,128 & 0,000 & 0,005 \\
Serang & $-0,072$ & 0,166 & 0,668 & 0,214 & 0,039 & 0,000 & 0,155 \\
Kota Tangerang & $-0,071$ & $-0,083$ & 0,929 & 0,293 & 0,177 & 0,000 & 0,004 \\
Kota Cilegon & $-0,067$ & 0,140 & 0,709 & 0,245 & 0,065 & 0,000 & 0,103 \\
Kota Serang & $-0,103$ & 0,114 & 0,723 & 0,274 & 0,104 & 0,000 & 0,091 \\
Kota Tang-Sel & $-0,060$ & $-0,086$ & 0,926 & 0,261 & 0,177 & 0,000 & 0,006 \\
\hline
\end{tabular}

\subsection{Aplikasi Model Mixed Geographically Weighted Reggression (MGWR)}

Pada analisis MGWR diawali dengan uji kesesuaian model. Pengujian ini dilakukan dengan hipotesis sebagai berikut :

$$
\begin{aligned}
& \mathrm{H}_{0}: \beta_{k}\left(u_{i}, v_{i}\right)=\beta_{k} \quad \text { dengan } k=1,2, \ldots, 9, \text { dan } i=1,2, \ldots, 8 \\
& \mathrm{H}_{1}: \text { minimal ada satu } \beta_{k}\left(u_{i}, v_{i}\right) \neq \beta_{k}
\end{aligned}
$$

Dengan menggunakan taraf signifikansi $\alpha$ sebesar 5\% maka model MGWR secara simultan atau bersama-sama disimpulkan dengan menambahkan faktor lokasi, bahwa model yang didapatkan berbeda secara signifikan dengan regresi linier. Hasil disajikan pada Tabel 3.

Tabel 3 Uji Kesesuaian Model MGWR

\begin{tabular}{lrrrrr}
\hline Sumber keragaman & SS & Df & MS & F1 & P_value \\
\hline Improvement & 2,3714 & 7,1936 & 0,3297 & 14,1217 & 0,0000 \\
MGWR & 0,3456 & 14,8064 & 0,0233 & & \\
Regresi & 2,7170 & 22,0000 & & & \\
\hline
\end{tabular}

Langkah selanjutnya dalam analisis MGWR adalah pengujian parameter serentak baik secara lokal maupun global. Cara yang digunakan untuk mengelompokkan variabel lokal dan global yaitu dengan melihat parameter apa saja yang berpengaruh pada model GWR. Dengan menggunakan tingkat signifikansi $\alpha$ sebesar 5\% untuk parameter lokal disimpulkan bahwa variabel prediktor lokal secara serentak berpengaruh terhadap pertumbuhan ekonomi di provinsi Banten. Kemudian parameter global dikatakan bahwa variabel prediktor global secara serentak berpengaruh terhadap pertumbuhan ekonomi di Provinsi Banten. Hasil disajikan dalam Tabel 4.

Selanjutnya dilakukan uji parsial parameter model MGWR baik lokal maupun global, hal ini dilakukan untuk mengetahui variabel mana saja yang berpengaruh signifikan terhadap respon pada model MGWR. Dengan menggunakan tingkat signifikansi $\alpha$ sebesar 5\% untuk menguji estimasi parameter global, disajikan dalam Tabel 5. Variabel prediktor (X) yang signifikan pada Tabel 5 mengartikan bahwa benar variabel tersebut secara global berpengaruh secara signifikan terhadap respon pada model MGWR. Sedangkan variabel yang berpengaruh secara lokal kemudian dilakukan pengujian secara parsial seperti terlihat pada Tabel 6. Apabila $P$-value $<\alpha$ dalam Tabel 6 artinya variabel prediktor $\left(\mathrm{X}_{\mathrm{k}}\right)$ pada lokasi ke-i signifikan mempengaruhi variabel respon (pertumbuhan ekonomi) di lokasi tersebut untuk model MGWR. 
Tabel 4 Uji Serentak Parameter Global dan Parameter Lokal Model MGWR

\begin{tabular}{lrrrrr}
\hline Parameter Global & \multicolumn{1}{l}{ SS } & df & MS & F & P_Value \\
\hline Source & 1,9819 & 6,4789 & 0,3059 & 13,1044 & 0,0000 \\
\hline Improvement & 0,3456 & 14,8064 & 0,0233 & & \\
MGWR & 2,3276 & 21,2853 & & & \\
Reduced & & & & & \\
\hline Parameter Lokal & SS & df & MS & F & P_Value \\
\hline Source & 10,0632 & 10,1936 & 0,9872 & 42,2896 & 0,0000 \\
Improvement & 0,3456 & 14,8064 & 0,0233 & & \\
MGWR & 10,4088 & 25,0000 & & & \\
Reduced & & & & & \\
\hline
\end{tabular}

Ket: Source: Sumber Keragaman, Improvement: keragaman hasil perubahan model Reduced ke model MGWR, MGWR: keragaman model MGWR, Reduced: Keragaman model tanpa variabel Global/Lokal.

Tabel 5. Estimasi parameter global model MGWR

\begin{tabular}{crrrl}
\hline Variabel (X) & Beta & t_hitung & P_Value & Kesimpulan \\
\hline 3 & 0,0258 & 0,4099 & 0,3437 & Tidak signifikan \\
4 & $-0,1424$ & $-1,3174$ & 0,1034 & Tidak signifikan \\
5 & $-0,1217$ & $-2,0156$ & 0,0307 & signifikan \\
6 & 0,0426 & 0,6438 & 0,2645 & Tidak signifikan \\
7 & 0,0983 & 0,9172 & 0,1865 & Tidak signifikan \\
8 & 0,9573 & 5,046 & 0,0001 & signifikan \\
9 & $-0,0115$ & $-0,2477$ & 0,4038 & Tidak signifikan \\
\hline
\end{tabular}

Tabel 6 Estimasi Parameter Lokal Model MGWR dengan Pembobot Gaussian

\begin{tabular}{lrcccccc}
\hline Kabupaten/Kota & $\begin{array}{c}\text { Beta } \\
\text { konstan }\end{array}$ & $\begin{array}{c}\text { Beta } \\
\text { (X1) }\end{array}$ & $\begin{array}{c}\text { Beta } \\
(\mathbf{X} 2)\end{array}$ & $\begin{array}{c}\text { t hitung } \\
(\mathbf{X 1})\end{array}$ & $\begin{array}{c}\text { t hitung } \\
\text { (X2) }\end{array}$ & $\begin{array}{c}\text { P_value } \\
\text { (X1) }\end{array}$ & $\begin{array}{c}\text { P_value } \\
\text { (X2) }\end{array}$ \\
\hline Pandeglang & 0,7863 & $-0,0195$ & 0,6243 & $-0,0654$ & 0,9423 & 0,4743 & 0,1802 \\
Lebak & 0,5738 & $-0,0130$ & 0,3404 & $-0,0196$ & 0,6625 & 0,4923 & 0,2587 \\
Tangerang & $-1,1094$ & $-0,0093$ & 1,2244 & $-0,1282$ & 10,836 & 0,4498 & 0,0000 \\
Serang & 1,3268 & $-0,0057$ & 3,4139 & $-0,0548$ & 6,7544 & 0,4785 & 0,0000 \\
Kota Tangerang & $-1,1154$ & 0,0117 & 1,2462 & 0,1583 & 12,907 & 0,4381 & 0,0000 \\
Kota Cilegon & 1,3087 & 0,0050 & 3,4034 & 0,0492 & 6,7794 & 0,4807 & 0,0000 \\
Kota Serang & 1,1469 & 0,0293 & 3,1243 & 0,2941 & 6,8961 & 0,3863 & 0,0000 \\
Kota Tang-Sel & $-1,124$ & 0,0115 & 1,2399 & 0,1579 & 12,813 & 0,4383 & 0,0000 \\
\hline
\end{tabular}

\subsection{Pemilihan Model Terbaik}

Berikut pada Tabel 7 hasil untuk perhitungan AIC dan $\mathrm{R}^{2}$ untuk semua model regresi linier, GWR dan MGWR. 
Tabel 7. Hasil AIC dan $\mathrm{R}^{2}$ untuk model regresi linier, GWR dan MGWR

\begin{tabular}{lrr}
\hline Model & AIC & $\mathrm{R}^{2}$ \\
\hline Regresi Linier & 47,094 & 0,87 \\
GWR & 54,229 & 0,95 \\
MGWR & 30,109 & 0,99 \\
\hline
\end{tabular}

Apabila dibandingkan antara model Regresi Linier Global, GWR dan MGWR menggunakan Akaike Information Criteria (AIC) maka model MGWR merupakan model yang terbaik dikarenakan memiliki nilai AIC yang paling rendah, dengan hasil AIC untuk model Regresi Linier sebesar 47,094, AIC GWR sebesar 54,229 dan AIC MGWR sebesar 30,109. Apabila dilihat dari nilai koefisien determinasi $\left(\mathrm{R}^{2}\right)$ pun MGWR masih menjadi model yang terbaik dengan nilai yang terbesar yaitu $\mathrm{R}^{2}$ regresi linier sebesar $87 \%$, GWR sebesar 95\% dan MGWR sebesar 99\%. Dengan demikian MGWR merupakan model terbaik untuk menggambarkan fenomena pertumbuhan ekonomi di Provinsi Banten berdasarkan kondisi tiap Kabupaten/Kota.

\section{KESIMPULAN}

Pemodelan dengan menggunakan MGWR pada studi kasus pertumbuhan ekonomi di Provinsi Banten secara keseluruhan lebih baik dari pada model regresi linier dan GWR, ditunjukkan dengan nilai AIC yang terendah dan nilai $\mathrm{R}^{2}$ yang terbesar. Kelebihan model MGWR yaitu mampu menjelaskan fenomena lain dari model GWR, dimana dalam sebuah model bisa saja ada variabel yang tidak berpengaruh secara lokal namun memiliki pengaruh secara global atau keseluruhan. Variabel yang berpengaruh secara global atau bersifat keseluruhan yaitu realisasi penerimaan PBB dan rata-rata lama sekolah. Variabel yang berpengaruh secara lokal yaitu modal yang berasal dari Pemda dan banyaknya industri dengan skala besar dan sedang, namun nantinya model akan berbeda untuk setiap lokasi tergantung dari variabel tersebut yang signifikan untuk masing-masing kabupaten/kota.

\section{DAFTAR PUSTAKA}

BPS, 2018. Berita Resmi Statistik. https://banten.bps.go.id/pressrelease.html [diakses tanggal 17 Mei 2018]

Draper, N., dan Smith, H. 1992. Analisis Regresi Terapan. PT. Gramedia Pustaka Utama. Jakarta.

Fotheringham, A.S., Brundson, C. dan Charlton, M. 2002. Geographically Weighted Regression. John Wiley and Sons, Chichester, UK.

Hakim, A.R., Yasin, H., dan Suparti. 2014. "Pemodelan Persentase Penduduk Miskin Di Kabupaten Dan Kota Di Jawa Tengah Dengan Pendekatan Mixed Geographically Weighted Regression”, Jurnal Gaussian Vol.3, No. 4. ISSN 2339-2541.

Ispriyanti, D., Yasin, H., Warsito, B., Hoyyi, A. dan Winarso, K. 2017. Mixed Geographically Weighted Regression Using Adaptive Bandwidth to Modeling of Air Polluter Standard Index. ARPN Journal of Engineering and Applied Sciences Vol. 12 No. 15, pp 4477-4482. 
Irawan dan Suparmoko, M. 2002. Ekonomika Pembangunan. Edisi Keenam. BPFE:Yogyakarta

Lesage, J.P. 2001. A Family of Geographically Weighted Regression Models. University of Toledo.

Mei, C.L., Wang, N., dan Zhang, W.X. 2006, “Testing The Importance of The Explanatory Variables In a Mixed Geographically Weighted Regression Model”, Environment and Planning A, Vol. 38, pp 587-598.

Prabowo, F.K.H., Wilandari, Y., dan Rusgiyono, A., 2015, "Pemodelan Pertumbuhan Ekonomi Jawa Tengah Menggunakan Pendekatan Least Absolute Shrinkage and Selection Operator (LASSO)”, Jurnal Gaussian Vol.4, No. 4. ISSN 2339-2541.

Purhadi dan Yasin, H. 2012. Mixed Geographically Weighted Regression Model Case Study: The Percentage Of Poor Households In Mojokerto 2008. European Journal of Scientific Research, Vol. 69, Issue 2, pp 188-196.

Yasin, H., Warsito, B., Ispriyanti, D. dan Hoyyi, A. 2017. Komputasi Metode Mixed Geographically Weighted Regression Menggunakan Graphical User Interface (GUI). Prosiding Seminar Nasional Statistika FMIPA Unpad (SNS IV) ISSN: 20872590.

Winarso, K. dan Yasin, H. 2016. Modeling of Air Pollutants SO2 Elements using Geographically Weighted Regression (GWR), Geographically Temporal Weighted Regression (GTWR) and Mixed Geographically Temporal Weighted Regression (MGTWR). ARPN Journal of Engineering and Applied Sciences Vol. 11 No. 13, pp 8080-8084.

Zeng, C. et al. 2016. Mapping Soil Organic Matter Concentration at Different Scales Using a Mixed Geographically Weighted Regression Method. Geoderma 281. pp 69-82. DOI:10.1016/j.geoderma.2016.06.033. 